Т. В. Мелкумова

\title{
СТИЛЬОВА ТА ЖАНРОВА ДИФЕРЕНЦІАЦІЯ МОВЛЕННЯ ЗАСОБІВ МАСОВОЇ ІНФОРМАЦІІІ В СУЧАСНОМУ МОВОЗНАВСТВІ
}

Мелкумова Т. В. Стильова та жанрова диференціація мовлення засобів масової інформації в сучасному мовознавстві.

У статті порушено проблему функціонально-стильового статусу мовлення засобів масової інформації, розглянуто внутрішньостильовий розподіл інформаційного та публіцистичного стилів, окреслено перспективи досліджень інформаційних та публіцистичних жанрів у зв'язку з активізацією суспільно-політичного життя.

Ключові слова: мовлення засобів масової інформації, інформаційний стиль, публіцистичний стиль, жанр.

Мелкумова Т. В. Стилевая и жанровая дифференциация языка средств массовой информации в современном языкознании.

В статье поднимается проблема функционально-стилевого статуса языка средств массовой информации, рассматривается внутристилевой раздел информационного и публицистического стилей, определяются перспективы исследований информационных и публицистических жанров в связи с активизацией общественно-политической жизни.

Ключевые слова: язык средств массовой информации, информационный стиль, публицистический стиль, жанр. linguistic.

Melkumova T. V. Style and genre differentiation of mass-media speech in modern

The article deals with problem of functional-style status of mass-media speech, inwardstylistic distribution of informative and publicistic styles, the perspectives of investigation of informative and publicistic genres connecting with activation of publicpolitical life are also determined in the article.

Key words: the language of mass-media, informative style, publicistic style, genre.

Останнім часом у зв'язку з активізацією суспільно-політичного життя, яка спричинила, зокрема, й підвищення ролі 3МІ, посилився інтерес до мовного аспекту їх функціонування. Публіцистичне мовлення в ораторському різновиді існувало задовго до появи 3МI, публіцистика в їі сучасних обсягах є широко розвиненим функціональним стилем, багатим на форми та засоби вираження. Функціонування публіцистичного підстилю в ЗМІ не ви- 
кликає жодних заперечень (І. Білодід, М. Жовтобрюх, Б. Кулик, М. Плющ, В. Токар та ін.). Проте не всі тексти у ЗМІ відносяться до публіцистики, мовознавці обгрунтовано доводять виокремлення IC як самостійного функціонально-стильового різновиду мовлення (Ю. Арешенков, Д. Баранник, Т. Добросклонська, В. Зайцева, М. Ковальчук, Т. Коць, Г. Мельник, А. Медушевський, Н. Озерова, І. Онищенко, Н. Разінкіна, В. Русанівський, А. Тепляшина, I. Шашкін та ін.). Інші дослідники обстоюють його позицію як підстилю публіцистики (Н. Бабич, М. Брандес, М. Феллер та ін.). Інколи до переліку функціональних стилів мовознавці вводять мовлення електронних засобів комунікації (Є. Какоріна), ораторський стиль (А. Медушевський). Попри всі здобутки мовознавства, функціонально-стильова диференціація мовлення ЗМІ залишається проблемою сучасної стилістики, лінгвістики загалом. Метою статті є порівняльний аналіз та узагальнення поглядів лінгвістів на проблему диференціації інформаційного та публіцистичного мовлення в сучасних $3 \mathrm{MI}$.

При виділенні функціонального стилю мовознавці покладаються в основному на один із двох базових стилетворчих чинників: розглядають стиль або через реалізовану функцію, або через сферу використання. Окрім того, дослідники виділили інші екстралінгвістичні та мовні характеристики, за якими можна розрізнити стилі. Більшість лінгвістів погоджується, що функціональний стиль має специфічні мовні ознаки на лексичному, фразеологічному, морфологічному, синтаксичному, композиційно-мовленнєвому мовному рівнях. Морфемні (П. Дудик) і фонетичні (І. Арнольд, Н. Разінкіна) особливості згадуються як такі, що відіграють незначну роль при визначенні стилю тексту. Стилетвірними є певні закономірності вибору, комбінування, модифікації та організації мовних засобів, в основному, лексичного та граматичного рівнів $[11,54]$. Як зауважує I.В.Арнольд, «стилі різняться як можливістю чи неможливістю використання тих або інших елементів і конструкцій, а також їх частотним співвідношеннями» $[3,246]$. Аналізу мовних особливостей публіцистичного та інформаційного мовлення приділяється значна увага в широкому колі мовознавчих досліджень [3; 6; 11; 20 та ін.]. Екстралінгвістичні (позамовні) стилетвірні фактори досить часто стають об'єктом розвідок 3 функціональної стилістики [1; 11; 16; 17 та ін.]. Більша кількість розбіжностей стосується стильової диференціації публіцистичного та інформаційного мовлення за екстралінгвістичними факторами, а не за мовними параметрами. Спостерігається також різнорідність систем позамовних ознак у дослідженнях різних мовознавців. Учені відносять до первинних (основних) екстралінгвістичних чинників виокремлення функціонального стилю, наприклад, тип адресата, спосіб комунікації, що визначає писемний та усний різновиди мовлення (М. Брандес), типову ситуацію спілкування - офіційну або неофіційну тощо. Описано вторинні позамовні фактори, які формують риси підстилів і жанрів [17, 624]. Важливими екстралінгвістичними параметрами є сфера 
використання, функціональна спрямованість, мовна функція, стильові риси, форми існування $[2,11]$.

Інформаційний стиль склався у «результаті активізації масовоінформаційного виду діяльності суспільства» [1, 128]. Дискусія стосовно виділення інформаційного стилю бере початок ще в першій чверті XX ст., коли почалося обговорення функціонально-стилістичних особливостей мови газети $[8,232]$. Наприкінці XX ст. у публіцистичному стилі науковці фіксують значні зміни: посилення інформаційної функції засобів масової інформації, презентація відносин до адресата, націленість на комунікативний статус аудиторії, перетворення в жанровій системі [17, 664-665]. Мова 3МІ набуває ознак окремого стилю, на позначення якого мовознавці пропонують такі терміни: інформаційний стиль [2;8]; публіцистичний стиль на противагу ораторському (= у традиційній класифікації - публіцистика) [3]; газетний [3; 15;20]; газетно-інформаційний (Т. Коць), [14]; стиль масової інформації [16]. Дослідники, які розподіляють публіцистичний та інформаційний стилі, розмежовують останній на власне інформаційне та коментарне, аналітичне мовлення. Такою класифікацією інформаційного мовлення (на позначення підстилів використовуються різні, але синонімічні терміни) послуговуються Ю. Арешенков, Т. Добросклонська, Г. Мельник, I. Онищенко, Л. Пархонюк, А. Тепляшина та ін.

Власне інформаційний підстиль представлений жанрами інформації, зокрема хронікальної, розширеної; звіту, замітки, кореспонденції, повідомлення $[2,13 ; 8,233 ; 13,115-117,128-129 ; 20,46]$. Коментарний підстиль реалізується у жанрових різновидах аналітичної інформації, репортажу, коментаря, інтерв'ю, огляду $[2,13]$. Аналогічно розподіляє газетні матеріали Л. Пархонюк - за двома напрямками: інформативні та аналітичні тексти. Т. Добросклонська поділяє медіатексти на три типи - новини, інформаційну аналітику (коментарій) та публіцистику [5, 179]. Задля уніфікації термінів проводимо паралелі: новини - власне інформаційний підстиль, інформаційна аналітика - коментарний підстиль, публіцистика - публіцистичний підстиль. Г. Мельник і А. Тепляшина виокремлюють у журналістиці такі групи жанрів: інформаційні, аналітичні, художньо-публіцистичні. Репортаж та інтерв'ю віднесено ними до інформаційного підстилю [13]. Посилення ролі ЗМІ в житті сучасного суспільства спричиняє до виникнення нових жанрових різновидів, наприклад, експрес-інтерв'ю, експресопитування, ексклюзивне інтерв'ю. Поширеність журналістського розслідування, цікавого специфічними засобами здобуття інформації, пов’язують iз посиленням інформаційної функції в текстах 3МI [7, 115-116]. Важливим аргументом для виділення інформаційного стилю є мовні параметри публіцистичних та інформаційних текстів. Наприклад, якщо порівняти їх стосовно частотності уживання виражальних засобів, зокрема синтаксису, помічаємо надзвичайну виразність публіцистичного мовлення та помірну емоційність інформаційних текстів, багатство виражальних синтаксичних засобів публіцистики та їх виважений добір в інформаційному мовленні. 
У класифікації функціональних стилів Д. Баранника вихідним пунктом є форма мови - усна, писемна. Усне мовлення існує в діалогічній та монологічній формах. В українському усному монологічному мовленні Д. Баранник виділяє стилі відповідно до мети та функціональної настанови. інформаційний стиль виокремлений дослідником як мовлення повідомного призначення. Публіцистичний стиль характеризується за двома напрямками - як мовлення переконувального призначення (підстилі - власне публіцистичний, судовий, дискусійно-діловий) та мовлення оцінноузагальнювального призначення (церемоніальний підстиль) [18, 503-560]. Ю. Арешенков підстилями публіцистики пропонує вважати власне публіцистичний та ораторський різновиди $[2,12]$.

На думку учених, які інформаційне мовлення вважають підстилем публіцистичного стилю, інформаційні тексти з публіцистичними мають більше спільного, ніж відмінного. У межах публіцистичного стилю лінгвісти виокремлюють інформаційний підстиль, оскільки «відповідно до принципів традиційної класифікації в мовознавстві структура цього стилю не $\epsilon$ достатньою для виділення його в окремий функціональний різновид»[12, 41-42]. Підставами для виокремлення інформаційного різновиду публіцистики часто слугує сфера використання тексту, що простежується уже на рівні назви підстилю: газетно-журнальна публіцистика [4], інформаційно-публіцистичний [12], прикладний [19], газетний (В. Ерендженов), газетно-інформаційний (А. Мамалига, О. Пазяк), газетно-публіцистичний підстиль (Г. Волкотруб) Г. Лещенко, Т. Сербіна, О. Сковородніков, О. Степанова, Л. Шевченко та ін.). В інформаційному підстилі виділяють типи, підтипи, жанри та форми (усна й писемна). Насамперед тексти цього підстилю розподілені між двома основними типами: перший - власне інформаційний; другий - аналітичний, коментуючий, об'єктивно-інформативний [4, 199-203]. М. Брандес розподіляє власне інформаційний тип інформаційного підстилю на підтипи, кожен 3 яких у свою чергу представлений жанровими різновидами: офіційно-інформаційний підтип (замітка, повідомлення, хроніка, звіт, інтерв'ю); інформаційно-діловий підтип (комюніке, резюме документа, кореспонденція, звіт, огляд друку); неофіційно-інформаційний підтип (жанр стислої замітки); інформаційно-експресивний підтип (замітка). В аналітичному типі інформаційного підстилю також виокремлено підтипи та жанри: газетно-науковий підтип (стаття, замітка, огляд, хроніка, інтерв'ю, репортаж); узагальнюючо-директивний підтип (жанри передової статті та коментаря); урочисто-декларативний підтип (звернення, опис, привітання, заклик, гасло [4, 199-204]. Аналіз мовознавчих джерел стосовно класифікації публіцистики за підстилями та жанрами показав, що дослідники часто вважають найсуттєвішим параметром внутрішньостильової диференціації сферу використання тексту. Наприклад, фейлетон віднесено до жанрів газетної публіцистики поряд із репортажем, інтерв'ю, хронікою тощо $[17,150]$. До вторинних позамовних параметрів, які фор- 
мують підстилі та жанри, мовознавці зараховують умови спілкування та форми мовлення, не пов'язані з призначенням сфери свідомості та відповідного виду діяльності $[17,624]$.

Ті мовознавці, які не виокремлюють інформаційний стиль, на підставі різних позамовних і мовних чинників подають, окрім інформаційного підстилю, такі підстилі публіцистики: ораторський, науково-публіцистичний, радіожурналістський підстиль, художня публіцистика, телепубліцистика, кінопубліцистика, реклама [4; 6; 12], публіцистичні тексти інтернету [9]. Виокремлення в межах публіцистики ораторського підстилю не викликає сумнівів ні у тих лінгвістів, які виділяють інформаційний стиль, ні у тих, які розглядають інформаційне мовлення у складі публіцистики. До ораторського підстилю належать тексти усної форми наступних монологічних жанрів: монолог, виступ на суспільних зборах, у державних і суспільних організаціях; доповідь, яка може стосуватися соціально-політичної або політико-економічної теми, бути звітною на зборах, конференції, з’їзді; промова - політична, дипломатична, військово-патріотична, агітаційна, надмогильна, ювілейна або мітингова. Останнім часом спостерігається активізація ораторського мовлення, особливо його діалогічних і полілогічних жанрів: публічний диспут, бесіда, дискусія, полеміка $[2 ; 4 ; 6 ; 11 ; 17 ; 18]$.

Деякі мовознавці не виділяють художньо-публіцистичного підстилю, інші подають надзвичайно розлогий перелік його різновидів, до яких відносять, наприклад, більшість відомих у художньому стилі сатиричних жанрів (байки, гуморески, епіграми, афоризми і т. ін. [6, 90]). Представники обох точок зору орієнтуються при цьому на засоби реалізації текстів таких жанрів - газети, журнали. Так, дослідники, які не виокремлюють художньо-публіцистичного підстилю, відносять фейлетон до жанрів газетної публіцистики поряд із репортажем, інтерв'ю, хронікою тощо [17, 150]. Збільшується кількість дрібноформатних комічних художньо-публіцистичних жанрів, наприклад, досліджуваних Н. Станкевич політичних карикатур. Стилісти, які виділяють художню публіцистику, провідними іiі жанрами вважають оцінні тексти за функціональним призначенням - фейлетон і памфлет. Також художньо-публіцистичними визнаються есе, політичний трактат, пародія, нарис (останній буває портретним, проблемним, дорожнім) $[4 ; 6 ; 8 ; 17 ; 19]$. При віднесенні текстів цих жанрів до публіцистики треба враховувати не скільки реалізацію їх на сторінках друкованих 3МI, скільки відповідність функціональній настанові, мовним функціям та іншим параметрам функціонально-стильової диференціації.

Художньо-публіцистичний підстиль є наслідком пильної уваги митців слова до суспільно-політичних проблем. Художня публіцистика запозичила в художнього стилю жанрові різновиди, підпорядкувавши їх функціям публіцистики. Один і той самий жанр, наприклад, нарис, може бути різновидом як художнього стилю, так і художньо-публіцистичного підстилю. Проблема правильної функціонально-стильової ідентифікації свідчить про 
необхідність урахування реалізованої функції, так само, як і при розмежуванні публіцистичного та інформаційного стилю. Взаємопроникнення публіцистики й інших стилів на жанровому рівні $є$ перспективним напрямком дослідження різновидів публіцистичного мовлення.

Деякі мовознавці виокремлюють у складі публіцистики науковопубліцистичний підстиль, розгалужений на: теоретичні та науково-популярні статті, рецензії, лекції, виступи, доповіді [12, 41]. Наукові тексти мають непритаманні публіцистиці функціональну спрямованість (активізація логічного мислення адресата), мовні функції (волюнтативна, оцінна). Звичайно, публіцистичний текст може містити риси наукового стилю. Так, у політико-агітаційній статті використовують прийом аргументації із зверненням до історичних фактів. Але враховуючи інші параметри публіцистики, наприклад, вид діяльності у сфері використання публіцистичного підстилю (політико-ідеологічний), відмінний від виду діяльності у сфері використання наукових текстів (наукова діяльність), позиція учених щодо виокремлення науково-публіцистичного різновиду є недостатньо аргументованою.

Інколи в окремий підстиль відносять теле- та радіопубліцистику (С. Бернштейн, М. Кожина та ін.), що реалізується текстами теле- та радіопередач, політичних коментарів, оглядів $[4,197 ; 12,41]$. При виділенні подібних підстилів дослідники орієнтуються передусім на сферу їхньої реалізації, таким чином відбувається жанрова тавтологія в межах підстилів, адже одна й та сама доповідь може бути виголошена як у теле- або радіоефipi, так і в аудиторії або на мітингу. Теле- та радіодиспути, дискусії пропонують розглядати й у межах ораторського підстилю, його діалогічної та полілогічної форм.

Інколи дослідники виділяють в окремий ФС мовлення електронних 3МI (Є. Какоріна). Інтернет $є$ найменш дослідженим функціональною стилістикою засобом комунікації, так само, як і газета, ТБ, радіо, він постає контамінацією різних стилів (публіцистичного, інформаційного, офіційноділового, художнього та ін.), жанрів і різновидів мовлення (усних і писемних; монологічних, діалогічних і полілогічних). Публіцистичне мовлення здійснюється за трьома напрямками, наприклад, на порталі «Телекритика»: у текстах-«клонах» традиційних 3MI, у модифікованих текстах традиційних 3МI, в оригінальних веб-виданнях. Серед жанрових різновидів інтернет-публіцистики зустрічаємо зразки усіх відомих публіцистичних жанрів, а також появу нових специфічних. Наприклад, тематична дискусія форум стає одним із центральних й активних мовленнєвих жанрів в інтернеткомунікації, породжуючи нові різновиди (чат, конференція, гостьова книга) $[10,68-70]$. Інтернет активно досліджується щодо виражальних можливостей його текстів, перспективним є аналіз функціонально-стильової, жанрової різноманітності інтернет-мовлення. Новоутворені публіцистичні жанри інтернету є підставою для виділення його в окремий підстиль публіцистики. Інтернет має специфічні жанри, стрімко розвивається, істотно 
відрізняється від жанрів, наприклад, власне публіцистичного різновиду, за мовними характеристиками. Зворотній зв'язок публіциста з адресатом надзвичайно розвинений у багатьох формах. Є. Какоріна зазначає, що уперше засіб комунікації спрямував комунікативний процес не у вертикальному напрямку (диктор - слухач), а в горизонтальному (автор - адресат - автор). Що стосується інформаційних жанрів на сторінках інтернету, то вони є аналогічними до інформаційних різновидів в інших 3МI, тому не йдеться про віднесення їх до окремого підстилю інформаційного стилю.

Питання про стильовий статус реклами залишається дискусійним. На користь віднесення реклами до публіцистичного стилю наводяться такі аргументи: основні функції рекламних текстів (інформування, оцінка, вплив), мета (спонукання масового адресата до певної дії), соціальна значущість (зокрема в галузі економіки). Важливим компонентом змістової структури рекламного тексту є слоган - стисле, чітке й легке для сприйняття формулювання рекламної ідеї [17, 636-638]. Тексти рекламного підстилю популяризують певні твори, видовища, послуги 3 метою привернути до них увагу адресата. До рекламних жанрів зараховуються тексти плакатів, оголошень $[6,90]$. Логічним є віднесення політичної реклами до публіцистичного стилю, оскільки такий рекламний текст справляє ідеологічний вплив, модифікацію свідомості адресата, реалізує оцінну мовну функцію. Чи $є$ публіцистичним текстом реклама товару або послуги? Якими жанровими різновидами представлена сучасна реклама? Дослідження цих та інших питань стосовно реклами є перспективним напрямком дослідження.

Отже, визначення лінгвістичного статусу мовлення ЗМІ залишається проблемою функціональної стилістики. Лінгвісти, які вважають інформаційний стиль окремим функціонально-стильовим утворенням, орієнтуються при розподілі стилів головним чином на реалізовану функцію мови. Важливою відмінністю публіцистичного та інформаційного стилів є відповідність мовлення певному виду діяльності: інформаційне мовлення націлене на масово-інформаційну, публіцистичне - на політико-ідеологічну діяльність. Відмінності між двома стилями простежуються стосовно сфери використання, функціональної спрямованості та стильових рис, мовних функцій і ознак, зокрема, публіцистичний та інформаційний стилі відрізняються стосовно уживання синтаксичних виражальних засобів.

Мовознавці, що розглядають інформаційне мовлення як підстиль публіцистики, орієнтуються передусім на сферу використання. При такому розподілі до інформаційних хибно зараховуються тексти зовсім іншого функціонального призначення; відбувається заміщення поняття «інформаційний», яке відображає сутнісну характеристику тексту, назвами «газетний» (у значенні «реалізований на сторінках газети»), «журнальний».

Дослідження мовлення сучасних 3МІ є перспективним напрямком сучасної лінгвістики; проблемними є такі аспекти: функціонально-стильовий статус текстів реклами; дослідження зміненої системи різновидів теле- та радіопубліцистики; аналіз жанрових новоутворень в електронних 3МI; вза- 
ємопроникнення публіцистики та інших стилів на жанровому рівні. Вирішення лінгвістикою окреслених проблем сприятиме чіткому визначенню жанру, підстилю, функціонального стилю тексту, адже це закладає основи для його повноцінної характеристики.

\section{Література}

1. Арешенков Ю. Місце інформаційного мовлення в системі функціональних стилів / Ю. Арешенков // Східнослов'янські мови в їх історичному розвитку: Збірник наук. праць, присвячених пам’яті проф. С. П. Самійленка. - Ч. ІІ. Запоріжжя: ЗДУ, 1996. - С. 125-128.

2. Арешенков Ю. О. Стилістика української мови: [навч. пос. для студентів факультету української філології]. - Кривий Ріг : КрДПУ, 2002. - 20 с.

3. Арнольд И. В. Стилистика современного английского языка: Стилистика декодирования: [учебн. пособие]. - [3-е изд.]. - М.: Просвещение, 1990. - 300 с.

4. Брандес М. П. Стилистика текста. Теоретический курс: [учебник]. - [3-е изд., перераб. и доп.] / М. П. Брандес. - М. : Прогресс-Традиция; ИНФРА-М, 2004. -416 с.

5. Добросклонская Т. Г. Язык британской качественной прессы: новости, комментарий, публицистика / Т. Г. Добросклонская // Язык современной публицистики: Сб. статей / [Сост. Г. Я. Солганик]. - [2-е изд., испр.]. - М., 2007. C. $179-211$.

6. Дудик П. С. Стилістика української мови: [навч. посібник] / П. С. Дудик. - К. : ВЦ «Академія», 2005. - $368 \mathrm{c.}$

7. Дускаева Л. Р. Принципы типологии газетных речевых жанров / Л. Р. Дускаева // Язык современной публицистики: Сб. статей / [Сост. Г. Я. Солганик]. [2-е изд., испр.]. - М. : Флинта ; Наука, 2007. - С. 115-143.

8. Зайцева В. В. Інформаційний стиль в україномовній газеті / В. В. Зайцева // На ниві української філології : збірник наук. праць. - Дніпропетровськ : Пороги, 2003. - C. 232-240.

9. Иванов Л. Ю. Язык интернета: заметки лингвиста / Л.Ю.Иванов. http://www/ivanoff.ru.

10. Какорина Е. В. СМИ и интернет-коммуникация (области пересечения и проблемы взаимодействия) / Е. В. Какорина // Язык современной публицистики: Сб. статей / [Сост. Г. Я. Солганик]. - [2-е изд., испр.]. - М. : Флинта ; Наука, 2007. - С. 67-98.

11. Кожин А. Н. Функциональные типы русской речи: [учеб. пособие] / Кожин А. Н., Крылов О. А., Одинцов В. В. - М. : Высшая школа, 1982. - 223 с.

12. Мамчур I. Функціональні стилі мовлення в аспекті сучасного мовознавства / I. Мамчур // Дивослово. - 2001. - № 12. - С. 32-42.

13. Мельник Г. С. Основы творческой деятельности журналиста / Мельник Г. С., Тепляшина А. Н. - СПБ. : Питер, 2008. - 272 с.

14. Озерова Н. Г. Взаимодействие функциональных стилей в русском и украинском языках / Н. Г. Озерова // Русский язык и литература. - 2000. - № 1. - С. 14.

15. Разинкина Н. М. Функциональная стилистика (на материале английского и русского языков): [учеб. пособие]. - [2-е изд., испр. и доп.] - М. : Высшая школа, 2004. - $271 \mathrm{c}$.

16. Русанівський В. М. Співвідношення функціональних і експресивних стилів мови // Слово і труд: До сімдесятиріччя академіка І. К. Білодіда / [редкол.: 
Андерш І. Ф. , Жовтобрюх М. А. , Їжакевич Г. П. та ін.] - К. : Наукова думка, 1976. - С. 73-81.

17. Стилистический энциклопедический словарь русского языка / члены [редкол.: Баженова Е. А., Котюрова М.П., Сковородников А. П.]; под ред. М. Н. Кожиной. - [2-е изд., испр., доп.] - М. : Флинта ; Наука, 2006.- 696 с.

18. Сучасна українська літературна мова: Стилістика / за ред. І. К. Білодіда. - К. : Наукова думка, 1973. - 588 с.

19. Феллер М. Д. Стиль и знак: Стиль как способ изображения действительности / М. Д. Феллер. - Львов : Вища школа, 1984. - 168 с.

20. Шашкін І. Ю. Про основні риси газетного стилю / I. Ю. Шашкін // Питання стилістики української мови в її взаємозв'язку з іншими слов'янськими мовами: тези доповідей міжвуз. наук. конференції 15-19 жовтня 1963 р. / [редкол.: Карпенко Ю. О., Кузнєцов В. І. , Слинько І. І.]. - Чернівці, 1963. - С. 45-47. 